Eirini ARTEMI*

\title{
CLEMENT'S OF ALEXANDRIA TEACHING ABOUT THE CRYPTIC PHILOSOPHICAL TRADITION
}

Clement emphasizes the permanent importance of philosophy for the fullness of Christian knowledge, explains with special predilection the relation between knowledge and faith, and sharply criticizes those who are unwilling to make any use of philosophy. He speaks definitely against the sophists and against the hedonism of the school of Epicurus. For Clement the tradition of apocrypha is very different from the tradition of the Church. He insists that educated and mature Christians inevitably seek an understanding superior to that of catechesis, and in this progressive theology necessarily included philosophy. He underlines that God gave the Jews the Old Testament as a preparation for the uptake of Christ and gave the Greek philosophy for the same purpose. The Old Testament and Greek philosophy are two great tributaries of the same stream Clement explains with emphasis that the cryptic tradition leads the gnostic to become the embodiment of the presence of Christ in the world. Although the Christian tradition belongs to the Church, for this reason Clement doesn't refer frequently to the Church, because he makes reference to another tradition. At the same time he doesn't want to delete the genuine ecclesiastic tradition.

1. The apocryphic tradition of the Church. In the first few centuries after the death of Christ, a tradition that came to be known as Gnosticism produced a number of texts that defy modern conventional understanding of the life of Christ and the Apostles. These legends and gospels integrated philosophies from Greek, Persian, Egyptian, and other sources with the Christian narratives. Many of the tenets and beliefs presented in some texts were later seen as incongruent with Christ's teachings and Christianity's history. Subsequently, they were deemed heretical. Though never canonized and thought lost, discoveries of the past two centuries, especially the Nag Hammadi Texts, have brought many of these apocryphal works to light.

Apocrypha means "hidden things" in Greek. The Apocryphical books of the Bible fall into two categories: texts which were included in some canonical version of the Bible at some point, and other texts of a Biblical nature which have never been canonical. Generally, the Apocrypha are documents

* Eirini Artemi - Theologist \& Classical Philologist, MA \& Ph.D. of Theology of National and Capodistrian University of Athens, email: eartemi@theol.uoa.gr. 
that were not accepted into the canon of the New Testament by the Orthodox Church. Many apocrypha were the base for the development of the gnostic Knowledge ${ }^{1}$.

Gnostics believed that matter, whether it be the physical universe or the humanly body, is evil. It is obvious that there is a great tension between spirit and matter. This affects many of their beliefs and especially the way they

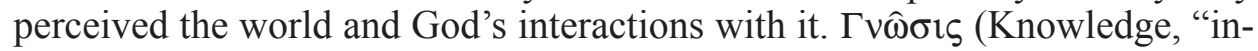
sight") is the only way for examining the universe, the human, the salvation of mankind and of course Jesus Christ ${ }^{2}$.

In Gnostic Christianity, spiritual gnosis is not just knowledge of facts or figures or an intellectual understanding of theological ideas. Rather, it is an experience. This knowledge or gnosis is subjective in its nature. The Gnostic doesn't just believe in God, he or she experiences God. Spiritual gnosis cannot be attained through the intellect. It is special initiatory knowledge given to the few who are ready to receive it. Through devotion and spiritual practice, the Gnostic has a revelatory experience that modifies human perception, and transfigures the individual ${ }^{3}$.

Gnosticism was one of the earliest heresies to arise in the Christian church and it is known mainly from the writings of Irenaeus of Lyon, who was one of its chief early opponents. Not all Gnostics believed exactly the same thing, but the general outlines of the belief are fairly clear. Gnostics were dualists, teaching that there are two great opposing forces: good versus evil, light versus darkness, knowledge versus ignorance, spirit versus matter. According to them, this world, the material cosmos, is the result of a primordial error on the part of a supra-cosmic, supremely divine being, usually called $\Sigma$ opí $\alpha$ (Wisdom) or

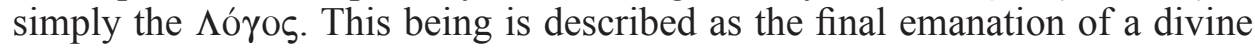
hierarchy, called the $\Pi \lambda \eta \dot{\eta} \omega \mu \alpha$ or "Fullness", at the head of which resides the supreme God, the One beyond Being ${ }^{4}$.

Since the world is material, and leaves much room for improvement, they denied that God had made it. How can the perfect produce the imperfect, the infinite produce the finite, the spiritual produce the material? - they asked. One solution was to say that there were thirty beings called aeons ( $\alpha i \hat{\omega} v \varepsilon \varsigma)$, and that God had made the first aeon, which made the second Aeon ( $\alpha i \omega$ v), which made the third, and so on to the thirtieth aeon ( $\alpha i \omega v)$, which made the world. This, Gnostics pointed out to the initiate, was the true inward spiritual meaning of the statement that Jesus was thirty years old when he began to preach. As anti-gnostic writers pointed out, this did not help at all. Assuming the Gnostic view of the matter, each of the thirty must be either finite or infinite, material

\footnotetext{
${ }^{1}$ Cf. J. Ferguson, Clement of Alexandria, New York 1974, 56-58.

${ }^{2}$ Cf. J. Daniélou, Les traditions secrètes des Apôtres, "Eranos Jahrbuch" 31 (1962) 17.

${ }^{3}$ Cf. S. Papadopoulos, Patrologia, vol. 1, Athens 1991, 145-150.

${ }^{4}$ Cf. ibidem.
} 
or non-material, and somewhere along the line you would have an infinite being producing a finite one, a spiritual being producing a material one ${ }^{5}$.

Generally, the Gnosticism was a very powerful spiritual phenomenon and result of mixture of different religions, such as paganism, Christianity, Persian and Greek philosophical theories. One of the main things which separated the Gnostics from Christians was the mysticism of their beliefs. It began with their views of God and creation. They viewed the One which they called the true God as having a feminine part which was the Spirit. In accord, they also held that Jesus came from God and the Spirit to form the Trinity. In the Gnostic version of creation of the world the Spirit of God is referred to as the Wisdom of God or Sophia who is also a feminine creative force. So the Gnosticism was a very dangerous movement for the Church and threatened Christians, because it devided the believers into two categories, the "perfect" and "purified" Christians who obtained the real Knowledge and the simple believers who obtained only the faith in Christ.

\section{Clement of Alexandria and the use of the apocryphal tradition in his} writings. Alain Le Boulluec points out that Clement speaks of two forms of written teaching ${ }^{6}$. The first comes in the form of the Hebrew Scriptures, which are clear to all according to a bare reading and provide the rudiments of the faith. Drawing on The Shepherd of Hermas, Clement tells us that this is reading Scripture according to the letter, rather than reading the hidden meaning according to the syllables ${ }^{7}$. The Scriptures are also then amenable to figurative expression which Gnostics advanced in faith are capable of understanding ${ }^{8}$. Clement emphasizes the permanent importance of philosophy for the fullness of Christian knowledge, explains with special predilection the relation between knowledge and faith, and sharply criticizes those who are unwilling to make any use of philosophy ${ }^{9}$. He pronounces definitely against the sophists and against the hedonism of the school of Epicurus. For Clement the tradition of apocrypha is very different from the tradition of the Church. Clement insists that educated and mature Christians inevitably seek an understanding superior to that of teaching of Bible, and in this progressive theology necessarily included philosophy ${ }^{10}$. He underlines that God gave the Jews the Old Testament as a preparation for the uptake of Christ, gave the Greek philosophy for the same purpose ${ }^{11}$. The Old Testament and Greek philosophy are two great trib-

${ }^{5}$ Cf. S. Hoeller, Gnosticism: New Light on the Ancient Tradition of Inner Knowing, Wheaton 2002, 2-55.

${ }^{6}$ Cf. A. Le Boulluec, Pour qui, pourquoi, comment? Les "Stromates" de Clément d'Alexandrie, in: Entrer en matière. Les prologues, ed. J.-D. Dubois - B. Roussel, Paris 1998, 23-36.

${ }^{7}$ Cf. Clemens Alexandrinus, Stromata VI 15, 131.

${ }^{8}$ Cf. A. Itter, Esoteric Taching in the Stromateis of Clement of Alexandria, Leiden 2009, 29.

${ }^{9}$ Cf. Clemens Alexandrinus, Stromata VII 16, 96.

${ }^{10} \mathrm{Cf}$. ibidem I 3, 5.

${ }^{11} \mathrm{Cf}$. ibidem. 
utaries of the same stream. Clement explains with emphasis that the cryptic philosophical tradition leads the gnostic to become the embodiment of the presence of Christ in the world ${ }^{12}$. Although the cryptic philosophical tradition differs from the Christian tradition which belongs to the Church, Clement doesn't refer frequently to the Church, because he makes reference to another tradition $^{13}$. At the same time he doesn't want to delete the genuine ecclesiastic tradition. Generally, the unwritten tradition comes down to Clement, who refers to it as the seeds of Knowledge which, through the need to be kept hidden, dictate the obscure form of the books of Stromateis ${ }^{14}$.

Clement was an early Greek Christian writer and presbyter whose works flourished in Alexandria in the late $2^{\text {nd }}$ century AD. He was a Christian Apologist, missionary theologian to the Greek cultural world, and second known leader of the catechetical school of Alexandria, after Pantaenus. He was the first theologian of the Christian Egypt. He was contemporary to Ireneaus of Lyon, but these two men represented two different theological traditions ${ }^{15}$. Ireneaus was the supporter of the apostolic tradition and Clement of the apocryphic one as well. Through his Clement's work, it is understood that it was not polemicizing about gnosticism as such, however, but was railing against false gnostics and their pernicious apocryphal writings ${ }^{16}$.

He synthesized Greek philosophical traditions with Christian doctrine and valued gnosis that with communion for all people could be held by common Christians specially chosen by $\operatorname{God}^{17}$. His writings can be thought as systematic treatises. They consist of introductions to Christian faith and life, and miscellaneous reflections on these subjects, leading up to his conception of the ideal advanced believer - the Gnostic. The writings of Clement disclose the amazingly broad scope of his knowledge of both classical and Biblical literature. On page after page of his treatises are copious citations of all kinds of literature. Generally, thus he is placed within the framework of a Christian faith which knows and accepts both a public and an esoteric (apocryphal) level

\footnotetext{
${ }^{12}$ Cf. ibidem I 5, 32.

${ }^{13} \mathrm{Cf}$. ibidem I 11, 50; VI 7, 61; VI 8, 62.

${ }^{14} \mathrm{Cf}$. ibidem VI 8, 64.

${ }^{15}$ Cf. Papadopoulos, Patrologia, vol. 1, p. 334.

${ }^{16}$ Cf. C. Wilfred Griggs, The Origin and Formation of the Corpus of Apocryphal Literature,
} in: Apocryphal Writings and the Latter-day Saints, ed. C. Wilfred Griggs, Salt Lake City 1986, 35: "Wilhelm Schneemelcher could write in 1959 (Neutestamentlichen Apokryphen in deutscher Übersetzung, vol. I, Tübingen 1959, 25-26) that it was in the conflict with gnostics that Clement wrote of some gnostics appealing to bibloi apokryphoi (Stromateis I 15, 69). Schneemelcher infers that Clement contributed to the ecclesiastical rejection of the use of apocryphal works by the heretics; but the discovery in 1958, by Morton Smith, of a portion of a letter from Clement of Alexandria to a certain Theodore makes such a position impossible. The primary purpose of Clement's letter was to warn the otherwise unknown Theodore against the corrupting influences of the Carpocratian gnostics".

${ }^{17}$ Cf. Clemens Alexandrinus, Stromata VI 10, 6. 
of doctrine ${ }^{18}$. Clement underlines that truth, justice and goodness can be seen only by the mind, not the eye; faith is a way of accessing the unseeable ${ }^{19}$. He stresses that knowledge of God can only be achieved through faith once one's moral faults have been corrected ${ }^{20}$.

Clement develops his apocryphic teaching mainly in his work Stromateis ${ }^{21}$ :

"The Stromateis will contain the truth mixed up with the opinions of philosophy, or rather covered over and hidden, as the edible part of the nut in the shell. For, in my opinion, it is proper that the seeds of truth be kept for the husbandmen of faith, and nobody else"22.

The knowledge is the leader of his spirit. He supports that the knowledge leads to the salvation. "For I will dare aver that it is not because he wishes to be saved that he, who devotes himself to knowledge for the sake of the divine science itself, chooses knowledge" 23 and he adds "Could we, then, suppose any one proposing to the Gnostic whether he would choose the knowledge of God or everlasting salvation" 24 . Clement affirms that philosophy had a propaedeutic role for the Greek, similar to the function of the law for the Jews ${ }^{25}$. On the other hand, the Holy Scripture is an innately true primal philosophy which is complemented by human reason through the $\operatorname{Logos}^{26}$. We must expound that knowledge, the gnosis is not the formal education for Clement. It is the comprehension of the things of the man's and nature's being. These things are thought reliable, because they are imparted and revealed by the incarnated $\log ^{27}$.

The most important experience of the gnostic man is the ability to conduct the investigation into the truth in a state of peace, advancing by the science of demonstration until he attains to comprehensive knowledge ${ }^{28}$. The belief in God is the first stage for the salvation. He believes that the only faith is for

${ }^{18} \mathrm{Cf}$. Wilfred Griggs, The Origin, p. 35.

${ }^{19} \mathrm{Cf}$. Clemens Alexandrinus, Stromata IV 3, 11-13.

${ }^{20} \mathrm{Cf}$. ibidem IV 7, 41.

${ }^{21}$ The Stromata goes further and aims at the perfection of the Christian life by initiation into complete knowledge. The first of these works is addressed to the unconverted, the second to the new Christian, and the third appeals to the mature believer. It attempts, on the basis of Scripture and Tradition, to give such an account of the Christian faith as shall answer all the demands of learned men. Clement entitled this work Stromateis, "patchwork", because it dealt with such a variety of matters. Cf. Papadopoulos, Patrologia, vol. 1, p. 35.

${ }^{22}$ Clemens Alexandrinus, Stromata I 1, 18, PG 8, 708B, transl. W. Wilson, in: Ante-Nicene Fathers, vol. 2 (=ANF), Grand Rapids 1885, 303.

${ }^{23}$ Ibidem IV 22, 135-136, PG 8, 1545C, ANF 2, 434.

${ }^{24}$ Ibidem.

${ }^{25} \mathrm{Cf}$. ibidem I 1, 15 .

${ }^{26}$ Cf. ibidem II 2,9 .

${ }^{27}$ Cf. ibidem VI 6, 46; Gal 5:19. See P. Karavites, Evil, Freedom, and the Road to Perfection in Clement of Alexandria, Supplements to Vigiliae Christianae 43, Leiden - Boston - Köln 1999, 145.

${ }^{28}$ Cf. Clemens Alexandrinus, Stromata IV, 6, 40. See Itter, Esoteric Teaching, p. 107. 
Christian who has simple way of thinking. Only few of the believers could go to another step for the salvation. They could be gnostic, take part in the upper stage of the spiritual life, of knowledge. However, Faith is voluntary, and the decision to believe is a crucial fundamental step in becoming closer to God.

This ecclesiastical writer explains that the gnostic conducts the research into the truth in a state of peace, advancing by the science of demonstration until she attains to comprehensive knowledge ${ }^{29}$. "But the most ancient of the philosophers were not carried away to disputing and doubting, much less are we, who are attached to the really true philosophy, on whom the Scripture enjoins examination and investigation" 30 .

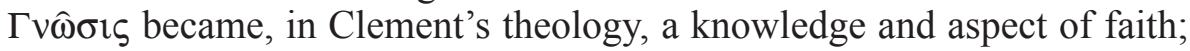
Gnosis needs the faith and bases on the latter ${ }^{31}$. He supports that the apocryphic tradition of the Church is called "gnostic" 32 . This tradition derived directly from the holy apostles, Peter, James, John, and Paul, the sons receiving it from the father, came by God's will to us also to deposit those ancestral and apostolic seeds ${ }^{33}$. The Gospel is the true Gnosis. Christianity is the way of salvation for all people and can only be appropriated by faith but the enlightened Christian could advance to knowledge. The content of the faith is summarized by the Church in her confession.

The Alexandrian theologian sees knowledge and aspect of life as a personal service that "loves and teaches the ignorant, and instructs the whole creation to honour God Almighty"34. Thus, Clement's Christian Gnostic witnessed to non believers, to heretics, and to fellow believers, the educated and uneducated alike, by teaching new insights and by setting a lofty example in moral living. Like the faithful Christians - those who claimed that man was saved by faith, which was to be demonstrated in legalistic and moral terms - Clement held that faith was the basis of salvation ${ }^{35}$; but, faithful them, he claimed that faith was also the basis of $\gamma v \hat{\omega} \sigma r \varsigma$, a spiritual and mystical knowledge. By distinguishing between two levels of believers, i.e. the faithful Christian, who responds through discipline and lives on the level of the law, and the Christian Gnostic, who responds through discipline and love and lives on the level of the gospel.

Clement underlines that in the Holy Bible there are two forms of written speaking: God who is speeking and the texts to be interpreted ${ }^{36}$. Through these, the gnosis is appeared. It has as a main scope the making of man a real

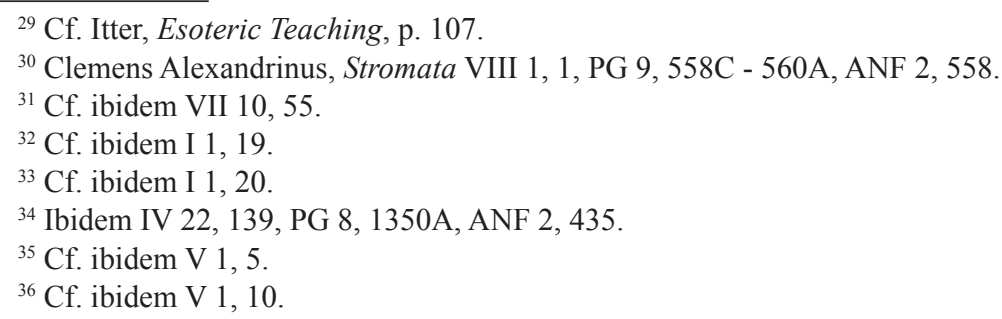


and perfect Christian. The knowledge of Christ as Logos brought salvation to

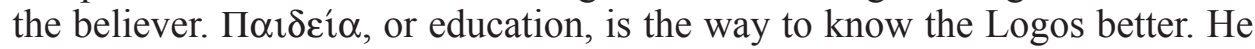
concedes that much of the Bible was better understood as allegory and not literal truth. He explains the plain meaning of the Bible through allegory brings in classical Greek philosophy ${ }^{37}$. He fosters elitism in his preference for the secret and more mature understanding of religious knowledge ${ }^{38}$. This gnosis comes through faith and illumination. Without the light which stems from God we cannot know Him as perfectly as possible ${ }^{39}$.

In his phrase "In a man who loves wisdom the father will be glad"40, Clement summarizes the basic meaning of his teaching. The essential characteristic of Christian faith in relation to the perfect Knowledge is the rapprochement of God. The faith is the product, the gift of holy Divinity. It is the sine qua non for the origin of faith. Of course faith is something less important than the Knowledge ${ }^{41}$, because faith, as we have said, is something given but the gnosis is the result of a difficult effort ${ }^{42}$. For God, the perfect man is who has faith and knowledge. Only faith cannot make him God's beloved one.

Clement doesn't refuse the ecclesiastic tradition, he underestimates this, because for him the apocryphic one is more perfect and full of truth. He can be thought neither as the heretic gnostic writer nor as genuine ecclesiastic father as Ireneaus. He could be characterized as gnostic Christian. He rarely refers to the Christian Church and this is a proof that he accepts the apocryphic tradition. On the other hand, when he speaks about the Church, he doesn't mean the historic Church which is established by Christ and Apostles and it was struggling to save the teaching of Christ ${ }^{43}$. The historic Church was for the believers.

For Clement, the Bible has hidden meanings to incite us to search and discover the words of salvation, which are hidden from those who despise them. The truth is in the pearls which must not be offered to the swine's. Clement did insist, however, that the Scriptures had a literal, historical sense - a primary meaning - that had to be respected. But allegorical reading could find further "spiritual" meanings containing universal and eternal truths.

Generally, Clement uses the apocryphic tradition as a way to obtain the knowledge. He didn't refuse that if a Christian wanted to become beloved by God, he should have not only the faith but the $\gamma v \omega \hat{\sigma} \sigma r \varsigma$ too. Such knowledge was the true $\gamma \nu \hat{\omega} \sigma ı \varsigma$, characterized by faith, not to be confused with the

${ }^{37}$ Cf. ibidem VII 11, 58.

${ }^{38} \mathrm{Cf}$. ibidem.

${ }^{39}$ Cf. ibidem VII 14, 73.

${ }^{40}$ Ibidem I 1, 22, PG 8, 713B, ANF 2, 302.

${ }^{41}$ Cf. ibidem VII 5, 50.

${ }^{42}$ Clement has in mind the Judeo-Christian God as He has been revealed through the prophets and Christ, not just a form of deism. Cf. M. Farantos, Peri Dikaiosynes. Systematic Ereuna eis to Ergon Klementos Alexandreos, Athens 1971, 163-164.

${ }^{43}$ Cf. Papadopoulos, Patrologia, vol. 1, p. 339. 
false $\gamma \nu \hat{\omega} \sigma ı \mathrm{~s}$ of the heretics, of the funs of gnosticism, which was incomplete because it was not grounded in knowledge of the Scriptures. Although, he constantly opposes the concept of $\gamma v \hat{\omega} \sigma \mathrm{r} \varsigma$ as defined by the Gnostics, he used the term "gnostic" for Christians who had attained the deeper teaching of the Logos. In his whole life, he tried to reconcile the knowledge with faith in Christ's revelation. Although, he is different in his ideas to the other fathers, he should not be seen as heretic. He lived and died as a Christian and as a faithful man of the Church of Christ.

3. The Logos in the thought of Clement of Alexandria. The idea of the Logos dominates his thinking. The divine Logos, creator of all things, guides all good men and causes all right thought. The presence of Logos is absolutely necessary for the receiving of Gnosis. Only through Logos, a man can know the Father and general the Triune God. The Son of God, Jesus Christ, made Himself the exhorter of men and women so that they set out towards the Truth with determination ${ }^{44}$.

Knowledge of Christ is not only thought, but is love which opens the eyes, transforms the person and creates communion with the Logos, with the Divine Word who is truth and life. In this communion, which is perfect knowledge and love, the perfect Christian attains contemplation, unification with God. Logos is the only being who knows the transcendent and incomprehensible God. For this reason, he could be the real mediator between God and man, between the creator and the creature. There is intrinsic affinity between Logos and the man, his logic. God's Logos is his image and the divine Logos is the authentic Son of His mind (vovs), the archetypal light of light, and the man is the image of $\operatorname{Logos}^{45}$.

He argued that the Logos functioned as a tutor and inspired man toward high moral endeavours ${ }^{46}$. Man is transformed by God's help into heavenly man thus fulfilling the biblical objective of making man into the likeness of God. Christ, he argued, is the image and the stage of becoming like God. We may desire to fulfil the Father's will and imitate the life of Christ. Jesus Christ himself becomes the $\Pi \alpha 1 \delta \alpha \gamma \omega \gamma$ ó $\varsigma$, that is, the "tutor" of those who, by virtue of Baptism, have henceforth become children of God.

Clement refers more to Logos than to Triune God. This was cause to be accused that he created a theology which was based on Logos and not God ${ }^{47}$. Clement's Logos-theology concerns the function, status, and role of the Son in

${ }^{44}$ Cf. Benedict XVI, Clement of Alexandria, General Audience, St. Peter's Square, Wednesday, 18 April 2007 (http://www.vatican.va/holy_father/benedict_xvi/audiences/2007/documents/hf_benxvi_aud_20070418_en.html [access: 31.12.2014]).

${ }^{45}$ Cf. H. Cunliffe-Jones, A History of Christian Doctrine, Edinburgh 1978, 66.

${ }^{46}$ Cf. F.L. Canale, Philosophical foundations and the biblical sanctuary, "Andrews University Seminary Studies" 36 (1998) nr 2, 183-206.

${ }^{47}$ Cf. K. P. Christou, Greek Patrology, vol. 2, Thessaloniki 1978, 794. 
relation to the Father. On the one hand, it emphasizes the Son's peculiar or paradoxical position as being distinct from the One as the knowable One-Many; and united with the One, on the other. Questions related to his pre-existence, generation, and divinity are also discussed ${ }^{48}$. For Clement, Logos is the mind of God containing the thoughts of God He is the law of all things and the educator of the $\operatorname{man}^{49}$.

Although, Clement refers most of times in Logos, it doesn't mean that he refuses the historic Christ. The incarnation of Christ is the basic factor for the Knowledge and for the man's redemption. In this spot, the alexandrian theologian was influenced by Philo's teaching about Logos.

Although, Clement was accused as a forerunner of heretic Arius. In relation to this charge it must be said that Clement's opinion is influenced by Philo's teaching, but he supports that Christ as "created" would challenge the core of the doctrine of salvation and redemption and understood and taught by mainstream Christianity ${ }^{50}$ As professor Papadopoulos adds that Clement has adopted the teaching of Logos with elements from the Philo's teaching, but he didn't make the absolutism of the perceived inferiority of the Son, as did Arius ${ }^{51}$.

The gnostic Christian and the apocryphic tradition are the most important teaching in the theology of Clement of Alexandria. The apocryphic tradition helps him to create the picture of the gnostic Christian. He refuses neither the evangelical teaching nor Christ is the Logos. He supports that evangelical word is poor and it cannot lead man in perfection. Clement believes that only the Gnostics attain a kind of perfection, even while they are living here in this world, for by the divine grace they become Christlike. He also assures that no man is perfect in all things at once. "I know no one of men perfect in all things at once, while still human, though according to the mere letter of the Law, except Him alone who for us clothed Himself with humanity [...] But Gnostic perfection in the case of the legal man is the acceptance of the Gospel, that he that after the Law may be perfect" ${ }^{\prime 52}$.

The secret knowledge that the Gnostics claimed to possess was acquired by perseverance in moral rectitude and observing of the Commandments, not but by a sudden illumination that enabled them to understand the ways of God, the universe and themselves. It was knowledge that freed them and re-

${ }^{48}$ Cf. K. Scouteris, History of Dogma, vol. 1, Athens 1998, 546.

${ }^{49}$ Cf. Clemens Alexandrinus, Stromata IV 15, 97.

${ }^{50}$ Cf. P. Ashwin-Siejkowski, Clement on Trial: the Evidence of the Heresy from Photius Biblioteca, Leiden 2010, 76.

${ }^{51}$ Cf. Papadopoulos, Patrologia, vol. 1, p. 342.

${ }^{52}$ Clemens Alexandrinus, Stromata IV 21, 130, PG 8, 1340C, ANF 2, 433. 
vealed the mysteries of truth, and rent the veil which concealed how God controlled the creation.

Generally, Clement of Alexandria emphasizes the following: I. The title "Gnostic" does not refer to a heretic but to the orthodox Christian who attains the divine $\gamma v \omega \hat{\sigma} \sigma \mathrm{s} \varsigma$ (Knowledge) from the Holy Spirit, by illumination through Christ (the Logos) in the light of the tradition of the church. Clement writes, "Here are the notes that characterize our Gnostic: first, contemplation; then the fulfilment of the precepts; finally the instruction of good men. When these qualities are encountered in a man, he is a perfect Gnostic. But if one of them is missing, then his Gnostic is crippled" ${ }^{3}$. Clement's $\gamma v \hat{\omega} \sigma \mathrm{r} \varsigma$ is animated by a basic concern for regulating one's life, it is above all a knowledge of the

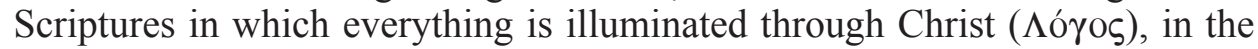
light of the tradition of the Church. II. Гvâoıs is the principle and author of every action conforming to the Logos. III. The Gnostic is called to know God ( $\gamma \imath \gamma \nu \omega ́ \sigma \kappa \varepsilon \imath v)$, to see God and to possess Him. IV. It is to the extent that the Gnostic attains this state that he becomes the equal of the angels. V. The grace of $\gamma v \omega \hat{\omega} \sigma \mathrm{i} \varsigma$ comes from the Father through the Son. VI. Christ is the source of knowledge ( $\gamma \nu \hat{\omega} \sigma \iota \varsigma)$, who grants us His knowledge through baptism, by making God known to us from the fact that the eyes of our souls are purified. VII. Christ gives us $\gamma v \omega \hat{\omega} \sigma ı \varsigma$ also through reading the Scriptures. VIII. The true Gnostic desires knowledge, struggles to practice goodness not in fear but in love. He is full of love towards God and men, fulfills the will of God, a man of prayer, witnessing to God daily (as a martyr), and never fears death. IX. Those who know (the Son) are called sons and gods. The Logos of God was made man so that you might learn how man can become god.

Clement lived as a Christian, he was a great ecclesiastical father. Although some ideas of his which were influenced by Plato and Philo's idea, he remained a faithful member of Church. He underlined that the only way to union with God - $\theta \dot{\varepsilon} \omega \sigma 1 \varsigma$ - is the Church's way. The simple faith of the baptized Christian contains all the essentials of the highest knowledge; $\gamma \nu \hat{\omega} \sigma ı \varsigma$ gives to Christian the perfection and the latter becomes the beloved of Christ.

\section{NAUCZANIE KLEMENSA ALEKSANDRYJSKIEGO O SEKRETNEJ TRADYCJI FILOZOFICZNEJ}

\section{(Streszczenie)}

Prezentowany artykuł, składający się z trzech części: tradycja apokryficzna w Kościele; Klemens z Aleksandrii i wykorzystanie tradycji apokryficznej w jego pismach; Logos w myśli Klemensa Aleksandryjskiego, ukazuje, jakie miejsce Klemens widział dla tradycji apokryficznej w nauczaniu Kościoła i swoich pis-

\footnotetext{
${ }^{53}$ Ibidem.
} 
mach. Klemens wyjaśnia z naciskiem, że sekretna tradycja filozoficzna prowadzi gnostyków do stania się ucieleśnieniem obecności Chrystusa w świecie. Ta sekretna tradycja filozoficzna różni się od tradycji chrześcijańskiej, przynależnej do Kościoła i dlatego Klemens nie odnosi się często do nauczania Kościoła, lecz odwołuje się do innej tradycji - do apokryfów. Jednocześnie nie chce pomijać prawdziwej Tradycji kościelnej. Ta niespisana tradycja, którą Klemens traktuje jako nasiona wiedzy, które z konieczności mają być trzymane w ukryciu, wpływa na formę i znajduje swe miejsce w księgach Stromatów.

Key words: Greek philosophy, Bible, gnosticism, perfect Christian, seeds of knowledge, Clement of Alexandria.

Słowa kluczowe: filozofia grecka, Biblia, gnostycyzm, doskonały chrześcijanin, nasiona wiedzy, Klemens Aleksandryjski. 
